\title{
"WAYANG PALEMBANG": ITS ORIGINS, CHARACTERISTICS, AND PRESERVATION FROM EXTINCTION
}

\author{
Endang Rochmiatun \\ Universitas Islam Negeri Raden Fatah Palembang \\ Email: endangrochmiatun_uin@radenfatah.ac.id
}

\begin{abstract}
Wayang Palembang is a traditional art of performing arts with artificial media of people made of leather. Wayang Palembang contains universal cultural values because it tells human life. This study describes the existence of Wayang Palembang through manuscript traces (ancient manuscripts). The research found that the Wayang Palembang was originally introduced by the ruling elites of the ruling Majapahit kingdom in Palembang. During the time of Palembang Sultanate this art modified by absorbing elements of Malay culture. Subsequently, he continued to be preserved during colonial and post independence. Wayang Palembang has unique characteristics that distinguish it from Javanese puppet, which is from the aspect of the introduction language by the Mastermind, the display of its own, or the performance devices, including the duration of the timing. This shows the harmonious acculturation and adaptation between Javanese culture and Palembang Malay culture. The heyday of the Palembang puppet period ended in 1980, with the last Dalang death.
\end{abstract}

Keywords: Palembang puppet, characteristic, preservation, extinction

\section{Introduction}

Traditional art is a national cultural heritage that is priceless and needs to be preserved. Palembang is known to be quite extensive and rich in cultural arts, and one of the existing cultural arts is in the form of "Puppet Palembang". Theoretically the puppet itself is a symbol that explains human existence in the form of a relationship between natural and supernatural powers (Mulyono 1982, 12).

Wayang is a traditional art form in Indonesia, a performing arts with the media of images or imitation of people (dolls) made of leather and wood. 
"WAYANG PALEMBANG": ITS ORIGINS, CHARACTERISTICS,

AND PRESERVATION FROM EXTINCTION

Endang Rochmiatun

Wayang as an artwork clearly contains universal cultural values. It is because the puppet talks about human life in general. When viewed from the role of the characters and the content of the story, the puppet story is the adaptations of the Mahabarata and Ramayana from India. In its development, this form of art wayang was used as a tool of preaching by the Wali Songo in Java with the intention to make Islamic teachings can be easily accepted by the community (Fattah 1996).

Puppet can also be said as a medium of communication because it is a type of art that is audiovisual which between the audience and the mastermind who play it will occur direct communication contacts so that it can create rides that can strengthen their fellow communities. Puppet can also be said to be a medium of communication that is very close to the daily life of society, because the puppet has some elements of its values. The elements of such values include: element of entertainment value, art value, education and lighting value, knowledge value, Rokhani value, music and symbolical (Sugito 1992). One of the educational values that can be intualized by Art media puppet through the story or Lakon (whether the story is inserted or with specific stories/plays) at the moment is: religious value, love of cleanliness and environment, honest, caring and the value of love of homeland.

Wayang art is known in various regions in Indonesia (both extinct and still preserved), one of which is Palembang. Although not clear since when and from where the origin of "Wayang Palembang", but a clear based on some relics that can still be found (one example is the story manuscript puppet) the existence of the wayang Palembang seems to have existed in the past (including the era of Palembang Sultanate). Palembang Puppet story manuscripts are also stored in the National Library of Indonesia, Balaputara Museum of Dewa, as well as in some manuscript-keeper communities in Palembang. Besides the manuscript, some relics of wayang equipment also stored by the heir or descendant of a mastermind Palembang (Iskandar 1986). 
Some sources say that the wayang Palembang is almost the same as the leather puppet in Java, so it can be suspected that the wayang Palembang originated from Java. The difference with Puppet in Java one of which is the language used by a puppeteer in grabbing the message, that is using the Malay language Palembang. The existence of Palembang puppet shows the existence of a meeting or contact culture that eventually creates acculturation and syncretization of culture, so that the translocal culture that mingle with the local culture can be buried in a puppet art.

At this moment it seems that the era of Palembang puppet can be said to be drowned or almost extinct. This is very concern because wayang art is one of the wealth of traditional art as a cultural heritage that needs to be preserved. This article will briefly review the existence of Palembang puppet that is suspected to have been very popular during the Sultanate of Palembang.

\section{Palembang Puppet presence: Historical perspective}

Palembang can be said as an heir of the arts that exist on the northern coast of Java island, such as music and drama art. According to the RMH Nato Dirajo, which is still a descendant of Palembang, this happened because the kingdom of Palembang became subordinate to Majapahit kingdom since 1365. After Ki Gede ing Temayan (officials from Java) came to Palembang in the 16th century, the language of the island of Java became a social language among the Keraton community of Palembang. In later times, the term commonly used in Java island such as the great country (the main area of the Kingdom) and Mancanagara (provincial region) became known and used in general. The princes usually control the territory Mancanagara the Kingdom of Palembang on the upstream and downstream. At that time, the foreign territory of the Kingdom of Palembang includes areas that are also inhabited by Besemah tribe (Kartomi 2012). 
"WAYANG PALEMBANG": ITS ORIGINS, CHARACTERISTICS,

AND PRESERVATION FROM EXTINCTION

Endang Rochmiatun

About since when the existence of Wayang Palembang, until now has not found many sources that mention for sure. However, one source mentions that at the time of Ario Damar (Ariodillah) ruling in Palembang (1455-1486M) There have been a set of tools in puppet Show and a "Dalang"(Boedanani 1961). The information instructed that Wayang has existed in Palembang since the time of Palembang under the Protectorate of Majapahit kingdom in Java, where the Duke at that time was Ario Damar (after entering Islam he was renamed to Ario Dillah or Ario Abdillah).

Wayang Palembang is actually a culture and art that has a distinctive character compared to the Javanese leather puppets Purwa origin. Unfortunately, the Palembang puppet show has lost its successor generation because the last puppeteer of the Palembang puppet using the Malay language dialogue, Ki Agus Rusdi Rashid, has passed away. Currently, there is practically no successor generation who mastered the puppet (Houtman 2017, 850).

Palembang Wayang Kulit is a form of puppet with the vision and version of the people of Palembang itself. This type of art is expected to grow around the 19th century (in the 1800s) during the reign of Arya Damar. The physical shape of the Palembang puppet is similar to that of the Javanese puppet Purwa. The difference between the two is the language in which the Indonesian wayang kulit is used in Palembang Malay (Selvi 2015, 2).

Hanafiah argued that the existence of wayang in Palembang is along with the formation of Keraton in Palembang by the Java elite. Wayang Palembang continues to evolve in Palembang community until the end of 20th century. One of the evidence is in the year 1943 held the puppet show of Palembang in the opposite of Ulu (Kertapati) area. At that time, Djohan Hanafiah was able to witness the show with $\mathrm{K}$. H Muhammad unengrossed (one of the scholars of Palembang). In addition, other information mentioned that the Palembang puppet show was last time at TVRI Palembang in 1983. 
Other iformations mentioned about the art of puppet show in Palembang. One of the information mentioned that the art of Wayang was brought to Palembang by the son of Sunan Kudus (one of the Wali Songo propagation of Islam in Java) named Mas Syahid (titled Panembahan Palembang) and Mas Nurdin (titled Prince of Palembang) (Iskandar 1986).

Regardless of which is right from some of the above sources, a lot of evidence suggests that the existence of wayang art in Palembang is sourced from the writing tradition that produces literary works, in the form of puppet story manuscripts. This shows that the art of wayang once existed in the past in Palembang, the era of Palembang Sultanate, colonial era, even post independence.

One source mentioned that in 1819 when there was a Menteng war where the Sultanate of Palembang fought against the Dutch colonial and won by the Sultanate, then the people of Palembang then held a celebration with the performances Puppet show at Beteng Kuto Besak for seven days and seven nights and cut the buffalo as much as 40 tails.

It can be said that the art of wayang originating from Java is what spawned the art of "Wayang Palembang". The phenomenon can be understood by the paradigm of "acculturation". According to Herskovits DKK (SJ 1984). Acculturation is defined as "... Those phenomena which result when groups of individuals having different cultures come into continous first-hand contact, with subsequent changes in the original cultural patterns of either on both groups ".

It can be said that the contact gives birth to the process of impersonation, unification, alteration of various cultural elements that come from the outside with cultural elements that have existed in the recipient society. As known, "Wayang Palembang" is a leather puppet as it is in Java, but in terms of language usage, "mastermind" puppet Palembang using Malay language Palembang. Besides, there are puppet figures that are given the title as well as the title in Palembang such as "Ki Agus Petruk", "Ki Agus Gareng" and so on. 
"WAYANG PALEMBANG": ITS ORIGINS, CHARACTERISTICS,

AND PRESERVATION FROM EXTINCTION

Endang Rochmiatun

\section{Palembang Wayang Manuscripts}

Based on some references there can be known that Palembang puppet story is divided into two types that are written in Javanese script and Arabic script. In the Museum Balaputra Dewa saved one manuscript of Javaneselanguage puppet titled Parta Krama. The text is narrated about the marriage between Arjuna and Dewi Supraba from Kayangan.

Palembang Puppet story script that is Arabic-language can be met in National Library RI numbered ML 235. The manuscript is not titled and contains three texts. The first text is a puppet story titled Bambang To ' Seno. The second text is a poem titled The Poem Sarikat Islam, and the third text is a puppet story titled Bambang Gandawardaya (Behrend 1998).

In the manuscript the text is composed of two types of writings, so it is thought that the author of the text consists of two authors. The first page up to page 30 seems to have been written by the script of the Islamic Poetry Company, the text is written in a very tightly so that it is less pronounced legible but seems neat and orderly. As for the text on page 31 to page 55 it seems to be written by the text-encoding Bambang To ' Seno with a somewhat less regular writing.

Colofon in the first text reads "End to 3 three months of Jumadil early night Sunday at $31 / 2$ the existence of the year 1336 is then is the one who wrote this is a pack Ahmad in Kampung 3 Ulu"

In addition to the manuscripts stored in the library and Museum, there are also puppet manuscripts that are stored by several manuscript owner's heirs in Palembang. The manuscripts that some Palembang people keep are:

\section{The Saga of Pendawa Lima}

This thick-shaped manuscript was preserved by R. H. Muhammad Akib. This manuscript condition is very concern. The manuscript seems to have been incomplete because there are some empty pages and many have torn the paper. 
Although the manuscript does not have a title and the text is somewhat difficult to read, it can be understood as the story of the Pendawa Lima.

\section{The tale of the Fall of Pendawa}

The owner of the manuscript was Mas Agus Haji Abdul Madjid bin Mas Agus Haji Agus who lived in Kampung 28 Ilir Palembang in $1340(\mathrm{H})$. The manuscript is now a collection of Nyimas Laili Yulita.

\section{Puppet Story}

The manuscript is a collection of H. M Zainuddin Syawaluddin. The condition of the manuscript has been of concern. The beginning and end of text is hard to read. The intent of the text is also difficult to understand. In the middle of the manuscript there is a picture of puppet which is described in it that Raden Arjuna and Mas Agus Patoruk brother Mas Agus Guring.

The existence of manuscripts from Palembang especially the literarythemed during the time of the Sultanate of Palembang can be understood, because the Sultan of Palembang himself showed his attention and his passion for culture. They are also protectors of literary activity. Especially Sultan Mahmud Badaruddin II, also known as the author of a number of poetry works.

\section{Palembang Puppet Performances at a Glance}

Wayang Palembang can be said not much different from the existence of Wayang Kulit in Java. Because Palembang puppet existence can not be separated with the history of the existence of Java elite that formed government in Palembang at the time. Based on information obtained, there are several differences in the performances of Wayang Palembang compared to Wayang kulit in Java.

Musical instrument or instrument used less, does not use Gedog, and does not wear a sinden. The instruments include: Saron, Bonang, xylophone, Gendang, rebab, Gong, Kecrek. Accompaniment songs are not sung by Snden, but only by using the Instrument tool. The audience only listened from the 
"WAYANG PALEMBANG": ITS ORIGINS, CHARACTERISTICS,

AND PRESERVATION FROM EXTINCTION

Endang Rochmiatun

mastermind play. Thus the beauty of the show depends on the creation of the mastermind. Therefore a puppeteer is required to be able to read the audience's situation.

The language used by puppet puppeteer Palembang follows the era. At first, the language used is Javanese, then can become Malay language Palembang. At first the puppet performances Palembang also carried out during the night SFOR, but the performance of Palembang Puppet in its development is done briefly that is about 3 hours, because it only takes the story of the point only or with the term The Padet (story summary). In short the time in the performance is intended so that the watch more understand and understand the essence of the Palembang puppet story.

Another characteristic of Palembang puppet is the way it looks, such as how to enter and how to speak the puppet figures are somewhat more free and less irregular. For example puppet figures that should come out of the left direction without obvious reasons out of the opposite direction, such as the antagonist Rahwana figure.

The story revolves around the story of Mahabarata and Ramayana. As an illustration, Rashid presents a sample of the following Palembang puppet performances:

Opening:

1. Song of Gending Sriwijaya

2. Setabik's Song

Jejer I : The national government of Gambang Kencono. Prabu Indrapuro was faced by Prabu Kencono, Raden Jago Arit, Raden Jago Kethu. After each chat about the state of the country, then Prabu Indrapuro gave instructions about the government. After that, Prabu Indrapura invited Raden Jago Arit and Raden Jago Kethu to Astino to search for Pendito Durno and would be used as a tumbal in Kencono country. Prabu Indrapuro handed the kingdom of Gambang 
Kencono to Prabu Kencono. Before leaving they enjoyed entertainment first together. Then the song is displayed: 1. Cup Mailang 2. Dara Bekhusek. After finishing the song, they depart.

Jejer II ; In the state boundary of Astino, Raden Jago, met Citraksi, who was then disputing to become a war. Citraksi was assisted by Raden Dursasono. Raden Snaron finally lost. By Prabu Indapuro, Raden Jago Arit and Raden Jago Kethu were told to follow in the palace Mencri Pendito Durno. Prabu Indrapuro against Dursasono. When the fights stopped, Raden Jago Arit and Raden Jago Kethu reported to Prabu Indrapuro that Pendito Durno escaped.

Jejer III : Caturan Pendowo. King Amarta before his brothers talked about the family and the kingdom. Then Prabu Amarta banned Raden arjuno against Raden Angko Wijoyo who had lost Petruk, Gareng and Bagong. He invites his brothers to help Semar who is saddened to think of his lost children. Suddenly there came Pendito Durno who was the reason for his arrival because he was kangen with the Pendowo family. Not long then came Prabu Indrapuro who asked that Pendito Durno be handed over to him. Pendowo's family retained his teacher, then there was war between Prabu Indrapuro against the Pendowo family. The people of the hall Fortunately, Prabu Dwarawati, a very thoughtful Kresno. He asked Semar to fight Prabu Indrapuro. Apparently Semar can defeat Prabu Indrapuro, even he changed to his native. It turns out that being/disguised as Semar as Prabu Inrapuro is Petruk.

\section{The Development of Palembang Puppet}

Wayang Palembang was developed and handed down hereditary limited in the family environment, especially by the ancestors of the Dalang Ki Agus Rusdi Rasheed. In this tradition, Wayang Palembang is played using the Malay 
"WAYANG PALEMBANG": ITS ORIGINS, CHARACTERISTICS,

AND PRESERVATION FROM EXTINCTION

Endang Rochmiatun

language Palembang, which is the original language of Palembang and has a resemblance to Javanese language. The Lakon or behavior of Palembang puppet figures are also more free (Subhi 2017). According to Sumari what is a mixture of Javanese and Malay culture, that is Palembang style in the tradition of the alliance in Palembang Capital of South Sumatera (Johansyah 2015, 2).

Based on a hereditary story in the family puppeteer Kiagus Wirawan is said that Wayang Palembang entered the land of Sriwijaya during the collapse of the kingdom of Sriwijaya. The empty power caused Majapahit to expand power into the region around 1370. But based on historical data search, there are three different kingdoms period on the journey of Wayang Palembang, namely 1) the beginning of the arrival of Wayang Purwa in the Land of Palembang, 2) the period of Purwa puppet and the invention of the form of Wayang Palembang, and 3) Wayang During the colonialization of Palembang (Fadila 2019, 42).

In the development of the puppet existence of Palembang is not sure if also a role in the process of Islamization in the area of Palembang (as the way of Da'wah Wali Songo in Java), or only as entertainment media only. This problem certainly needs further research.

Until the year 1984, which still keep the art of Wayang Palembang in Palembang only one group only, namely the group Sri Palembang. Palembang Puppet Group was founded by Rashid. He explores the data and information about the traditional arts of Palembang (Haryanto 1988).

One of the mastermind descendants that can still be found in Palembang at this time is Wirawan RUSDI (32 years). He is a descendant of a mastermind named Ki Agus Rusdi Rasheed (ALM). Currently he lives in the area of Kelurahan 36 Ilir, District Gandus. In his house can still be found some puppet equipment that Kelihataanya less to get decent maintenance so that it looks start to break. The equipments are: several puppets, and instrument equipment. It also explained that some of the puppet collections and equipment that had been owned by his parents had been destroyed because of a fire accident. 
From the color display aspect of Wayang Palembang also has differences with Javanese puppet. Javanese puppet has a golden color, while the wayang Palembang has copper yellow color. Other differences are also found in the performance aspects of the staging. The music used in the puppet staging of Palembang uses the gamelan which is the punch moves from left to right. This then produces a different sound with Javanese puppet music which blows on the gamelings moving from right to left (Margono, Sumardi, Astono 2007).

Generally, the mastermind in Palembang such as Ki Agus Rusdi Rasheed (ALM) who had played a role in the art of Wayang Palembang does not lose his skills or expertise to his descendants, so that the successor of Palembang's mastermind can be said no more.

The above facts are certainly very concern, because the art of "puppet" is one of traditional art richness that has been designated as cultural heritage should remain preserved. Therefore, there should be efforts from various parties to revitalize and revive the art of Wayang Palembang so that the unique traditions of the ancestral cultural heritage of Palembang people remain preserved and contribute to the treasures Very rich and varied national culture.

Palembang Puppet preservation certainly need to be done by involving several elements, among them is the Palembang cultural office. This business can be done by one of them by conducting revitalization of Wayang Art of Palembang. One of the steps that can be done is to conduct a caderisation for the young generation who have the interest and talent of the arts, for example in the form of training become the mastermind and supporting personnel of the Palembang puppet group. Socialization and promotion to the community through puppet performances in various major events will also help reintroduce Palembang puppet to the community. 
"WAYANG PALEMBANG": ITS ORIGINS, CHARACTERISTICS,

AND PRESERVATION FROM EXTINCTION

Endang Rochmiatun

\section{Conclusion}

Wayang Palembang art is one of the traditions and culture of Palembang Malay people who have a long history. This art was historically introduced by the ruling elites of the Majapahit Empire when Palembang became the protectorate of the kingdom. Then evolved and modified by accommodating elements of Palembang Malay culture during the Sultanate period, and continue to be preserved in the time of colonial and post-independence.

Wayang Palembang performances has a uniqueness and a good peculiarity in the language of introduction performed by the puppeteer, the display of its own, or the performance devices, including the duration of the timing of the introduction. This shows the harmonious acculturation and adaptation between Javanese culture and Palembang Malay culture.

Unfortunately, the golden days of Palembang puppet began to dim and ended in 1980, along with the death of last Palembang puppet mastermind. It can be said that at this time Palembang puppet era already drowned or extinct, either because there is no successor or cadres that preserve it, and also because of the shift or even competition with modern culture, such as the dominance of modern "pop" art More entertaining. Various people who were once filled by the show room "Wayang Palembang" has been ambushed by the show "Organ Tunggal". This occurs in almost all regencies and sub-districts in South Sumatera, including the city of Palembang.

On the other side of the young generation in South Sumatra, especially the Palembang city, it is also no longer interested to pursue traditional art in Palembang puppet show because it is considered less attractive, outdated, not promising income, and so on. Meanwhile, apparently from the local government in this case related to the field of culture has not had a concrete agenda to preserve one of the traditional cultural richness. We hope that someday we have a caring party and called to revitalize Palembang puppet art. 


\section{Bibliography}

Behrend. 1998. Katalog Induk Naskah-Naskah Nusantara Jilid 4. Jakarta: Yayasan

Obor Indonesia dan Ecole Francaise D'Extreme-Orient.

Boedanani. 1961. Tambo Kerajaan Sriwijaya. Bandung: Tarate.

Fadila, Aminatul. 2019. “Wayang Palembang Dalam Lakon Bambang Dharmojati

Oleh Dalang Kiagus Wirawan Bersama Sanggar Sri Palembang." Tari, teater, dan wayang 2(1): 42 .

http://journal.isi.ac.id/index.php/DTR/article/view/3299/1575.

Fattah, A. 1996. Metode Dakwah Wali Songo. Bandung: CV Sriwijaya.

Haryanto, S. 1988. Pratiwimba Adhiluhung: Sejarah Dan Perkembangan Wayang. Jakarta: Djambatan.

Houtman. 2017. "Pementasan Wayang Palembang: Pendidikan Karakter Melalui Eksplorasi Bahasa Dan Budaya Lokal." In Seminar Nasional Pendidikan PGRI 2017, Jakarta: Pengurus Besar Persatuan Guru Republik Indonesia (PB PGRI), 850. https://jurnal.univpgri-

palembang.ac.id/index.php/prosiding/article/viewFile/1215/1077.

Iskandar. 1986. Palembang Kraton Manuscripts" Dalam A Man of Indonesian Letters: Essays in Honour of Prof.A. Teeuw. Dordrecht: Foris Publication.

Johansyah. 2015. "Peran semar, gareng, dan petruk dalam pertunjukan wayang kulit palembang lakon prabu ukirgelung negak blabar kawat." Program pascasarjana Institut Seni Indonesia Surakarta. http://repository.isiska.ac.id/951/1/Tesis Johansyah.pdf.

Kartomi, Margaret. 2012. Musical Journeys in Sumatra. Champaign: University of Illinois Press.

Margono, Sumardi, Astono, Murtono. 2007. Seni Budaya Dan Keterampilan. Bogor: Yudhistira.

Mulyono, Sri. 1982. Wayang Dan Filsafat Nusantara. Jakarta: Gunung Agung.

Selvi. 2015. “Wayang Kulit Palembang." Palembang Tourism: 2.

http://www.palembang-tourism.com/berita-435-wayang-kulitpalembang.html.

SJ, J.W.M Bakker. 1984. Filsafat Kebuadayaan. Yogyakarta: Kanisius.

Subhi, Noperman. 2017. "Sejarah Dan Eksistensi Wayang Palembang." Majalah 1000guru. http://majalah1000guru.net/2017/05/wayang-palembang/.

Sugito, B. 1992. Dakwah Islam Melalui Media Wayang. Yogyakarta: Aneka. 
"WAYANG PALEMBANG": ITS ORIGINS, CHARACTERISTICS,

AND PRESERVATION FROM EXTINCTION

Endang Rochmiatun 